\title{
A COMPARISON OF THE EFFICACY OF NEW MONOPYRIDINIUM OXIMES WITH THE OXIME HI-6 AGAINST MEVINPHOS IN MICE
}

\begin{abstract}
Jiři Kassa, Jiř́ Bielavský
Purkyně Military Medical Academy, Hradec Králové: Department of Toxicology

Summary: 1. The therapeutic efficacy of three new monopyridinium oximes (2,4-PAEtM, 2,5-PAEtM, 2,5-PAAM) and the bispyridinium oxime HI-6 was evaluated in combination with benactyzine against acute poisoning with the organophosphorus insecticide mevinphos in mice. 2. When mice were treated two min after mevinphos poisoning, no significant differences in the therapeutic effectiveness of tested oximes were observed. They increased the $24 \mathrm{~h} \mathrm{LD}_{50}$ values of mevinphos about three times in comparison with non-treated intoxicated animals. 3. On the other hand, there were significant differences in their therapeutic efficacy when they were administered $30 \mathrm{sec}$ following mevinphos challenge. The monopyridinium oxime 2,5-PAEtM seems to be the most efficacious against mevinphos toxicity. 4. Use of new monopyridinium oxime 2,5-PAEtM appears to be the improvement in the antidotal treatment of poisoning with organophosphorus insecticide mevinphos in comparison with HI-6.
\end{abstract}

Key words: Mevinphos; Monopyridinium oximes; HI-6; Benactyzine; $L D_{50}$; Mouse;

\section{Introduction}

Organophosphorus insecticides (OPI) have become the most widely used class of insecticides in the world. The use of OPI in agricultural fields has replaced more resistant chlorinated hydrocarbon compounds. The choice of OPI is based on their properties of low bioaccumulation and high rate of biodegradation. They are also used in large quantities because of their high potential for insect knockdown capacity $(1,5)$. In spite of relatively low toxicity in comparison with highly toxic nerve agents, they have passed occupational hazards to workers employed in the application of these insecticides. Careless handling of OPI and their voluntary exposure with suicidal intent are the main reasons for intoxication $(12,17)$.

One of the most toxic OPI, mevinphos (2-methoxycarbonyl-1-methylvinyl dimethylphosphate), is used for its high efficacy against various insect species (4). The $24 \mathrm{~h}$ intramuscular (i.m.) $\mathrm{LD}_{50}$ of mevinphos for mice is $0.79 \mathrm{mg} / \mathrm{kg}$ body weight (18).

OPI induce clinical signs including salivation, diarrhea, lacrimation, tremors, convulsions and respiratory distress. Death from exposure to OP compounds is generaly due to respiratory failure from excessive airway secretions, construction of the airways and a loss of central respiratory control (13). Antidotal treatment of poisoning with OPI usually consists of anticholinergic drugs to counteract the accumulation of acetylcholine ( $\mathrm{ACh})$ and oxime reactivators to reactivate OPI-inhibited acetylcholinesterase (EC 3.1.1.7) (3).
The increased international concern about the possible accupational hazards to workers employed in application of OPI has prompted us to critically consider the expected value of currently available antidotal treatment of OPI poisoning. Unfortunately, none of currently available oximes can be regarded as a broad spectrum antidote (18). Although the bispyridinium oxime HI-6 (Figure 1) is considered to be the most efficacious oxime against highly toxic OP compounds including soman $(7,10,14)$, its therapeutic effectiveness against OPI poisoning is not quite satisfactory $(6,18)$.

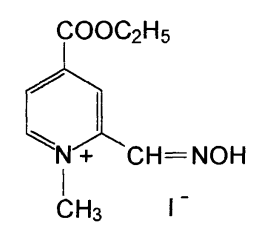

2,4 - PAEtM<smiles>C[n+]1cc(C(N)=O)ccc1C=NO</smiles>

2,5 - PAAM<smiles>COC(=O)c1ccc(C=N)[n+](C)c1</smiles>

2,5 - PAEtM

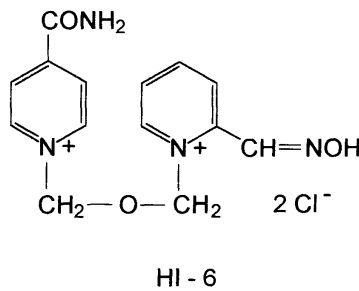

Fig. 1: Chemical structures of the oximes used 
To improve the efficacy of antidotal treatment of acute poisoning with OPI, three new monopyridinium oximes (2,4-PAEtM, 4-ethoxycarbonyl-2-hydroxyiminomethyl-1methylpyridinium iodide; 2,5-PAEtM, 5-ethoxycarbonyl2-hydroxyiminomethyl-1-methylpyridinium iodide and 2,5-PAAM, 2-hydroxyiminomethyl-5-carbonyl-1-methylpyridinium iodide) (Figure 1) have been synthesized at the Department of Toxicology of Purkyně Military Medical Academy in Hradec Králové.

The purpose of this study was to compare the efficacy of three new monopyridinium oximes (2,4-PAEtM, 2,5PAEtM, 2,5-PAAM) and the bispyridinium oxime HI-6 with anticholinergic drug benactyzine against multiple lethal doses of OPI mevinphos in mice.

\section{Methods}

Male mice (20-24g) obtained from Konárovice were housed in an air-conditioned room $\left(20-22^{\circ} \mathrm{C}\right)$ on $12-\mathrm{h}$ light/12-h dark cycles and were allowed access to food and tap water ad libitum. The principles of laboratory animal care were followed and the handling of animals was made under the supervision of the Ethics Committee of the Medical Faculty of Charles University and the Military Medical Academy in Hradec Králové.

The monopyridinium oximes (2,4-PAEtM, 2,5-PAEtM, 2,5-PAAM) were prepared by quaternization of tertiary bases by methyliodide in the medium of dimethylformamide and purified by crystallization from ethanol. Chemical structures of products obtained after synthesis were identified by an elemental analysis and NMR. The chemical purity of products of synthesis assessed by TLC was more than $98 \%$.

Mice were treated i.m. with oxime in equieffective doses $\left(5 \%\right.$ or $\left.10 \% \mathrm{LD}_{50}\right)$ in combination with benactyzine (BNZ) at a dose $8.4 \mathrm{mg} / \mathrm{kg} 30 \mathrm{sec}$ or two min following mevinphos (Spolana Neratovice) poisoning. $\mathrm{LD}_{50}$ values and $95 \%$ confidence limits were calculated by probit analysis of death occuring within $24 \mathrm{~h}$ after i.m. administration of mevinphos at five different doses with six mice per dose (15). The efficacy of antidotal mixtures tested was expressed as protective ratio $\left(\mathrm{LD}_{50}\right.$ of mevinphos in protected mice/LD $\mathrm{LD}_{50}$ of mevinphos in unprotected mice).

\section{Results}

The $\mathrm{LD}_{50}$ values of all oximes tested are shown in Table 1. Generally, the monopyridinium oximes are significantly less toxic for mice than the oxime HI-6.

Table 1: Toxicity parameters of oximes tested.

\begin{tabular}{|c|c|}
\hline OXIMES & $\mathrm{LD}_{50}(\mathrm{mg} / \mathrm{kg})$ \\
\hline HI-6 & $671.3(627.4-718.3)$ \\
\hline 2,4-PAEtM & $1560.3(1187.2-2050.6)$ \\
\hline 2,5-PAEtM & $1381.6(1267.6-1505.9)$ \\
\hline 2,5-PAAM & $1264.4(1160.3-1377.8)$ \\
\hline
\end{tabular}

The therapeutic efficacy of the monopyridinium oximes as well as the oxime HI-6 is presented in Table 2 and 3 . When the oximes in combination with BNZ were administered two min after mevinphos poisoning, the $24 \mathrm{~h} \mathrm{LD}_{50}$ values of mevinphos in treated mice were increased approximately three times in comparison with the $24 \mathrm{~h} \mathrm{LD}_{50}$ values in non-treated mice. No significant differences between effectiveness of the oximes tested were observed (Table 2).

Table 2: Therapeutic effect of oximes administered at $2 \mathrm{~min}$ after poisoning on the $\mathrm{LD}_{50}$ value of mevinphos.

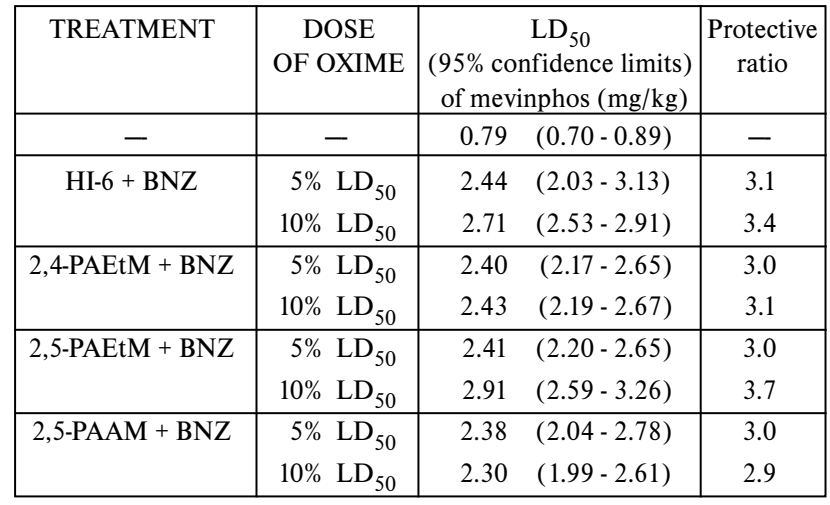

On the other hand, when mice were treated $30 \mathrm{sec}$ following mevinphos intoxication, the efficacy of all tested oximes was significantly increased and there were some differences in their therapeutic effect. The $24 \mathrm{~h} \mathrm{LD}_{50}$ values of mevinphos in mice protected with monopyridinium oxime 2,4-PAEtM or 2,5-PAEtM in combination with BNZ were increased 12 - 20 times in comparison with the $24 \mathrm{~h} \mathrm{LD}_{50}$ values in unprotected mice while the $24 \mathrm{~h} \mathrm{LD}_{50}$ values of mevinphos in mice protected with 2,5-PAAM plus BNZ were increased 6 - 8 times in comparison with the $\mathrm{LD}_{50}$ values in unprotected mice only. The effectiveness of the bispyridinium oxime HI-6 in combination with BNZ varied between them. The monopyridinium oxime 2,5-PAEtM seems to be the most efficacious oxime according to the $24 \mathrm{hLD}_{50}$ values (Table 3 ).

Table 3: Therapeutic effect of oximes administered at 30 sec after poisoning on the $\mathrm{LD}_{50}$ value of mevinphos.

\begin{tabular}{|c|r|rc|c|}
\hline TREATMENT & $\begin{array}{c}\text { DOSE } \\
\text { OF OXIME }\end{array}$ & $\begin{array}{c}\text { LD }_{50} \\
(95 \% \text { confidence limits }) \\
\text { of mevinphos }(\mathrm{mg} / \mathrm{kg})\end{array}$ & $\begin{array}{c}\text { Protective } \\
\text { ratio }\end{array}$ \\
\hline- & - & 0.79 & $(0.70-0.89)$ & - \\
\hline $\mathrm{HI}-6+\mathrm{BNZ}$ & $5 \%$ & $\mathrm{LD}_{5}$ & $9.73(9.10-10.40)$ & 12.2 \\
& $10 \% \mathrm{LD}_{50}$ & $12.09(10.83-13.48)$ & 15.1 \\
\hline 2,4-PAEtM + BNZ & $5 \% \mathrm{LD}_{50}$ & $10.09(8.06-12.74)$ & 12.8 \\
& $10 \% \mathrm{LD}_{50}$ & $13.85(12.90-14.90)$ & 17.5 \\
\hline 2,5-PAEtM + BNZ & $5 \% \mathrm{LD}_{50}$ & $13.89(13.30-14.53)$ & 17.6 \\
& $10 \% \mathrm{LD}_{50}$ & $16.05(15.09-17.40)$ & 20.4 \\
\hline 2,5-PAAM + BNZ & $5 \% \mathrm{LD}_{50}$ & $5.16(4.84-5.49)$ & 6.5 \\
& $10 \% \mathrm{LD}_{50}$ & $6.20(5.89-6.52)$ & 7.8 \\
\hline
\end{tabular}

Following antidotal treatment of mevinphos-poisoned mice at two min after intoxication, the similar intensity of 
clinical signs and symptoms attributable to ACh accumulation at cholinergic sites (salivation, lachrymation, convulsion of skeletal muscles and respiratory depression) were found. When antidotal treatment was administered $30 \mathrm{sec}$ following mevinphos challenge, a slight clinical improvement of mevinphos-poisoned mice treated with monopyridinium oxime 2,5-PAEtM or 2,4-PAEtM in comparison with the other oximes tested was observed.

\section{Discussion}

The oxime HI-6 has been shown to be very effective against some highly toxic OP compounds not only because of its high reactivating potency but also because of its other antidotal mechanisms based on antimuscarinic, antinicotinic and ganglion blocking actions as well as on restoration of neuromuscular blockade and beneficial effects on cardiovascular and respiratory systems $(2,11,16,19)$. On the other hand, HI-6 efficacy against OPI is not so high. It is not more effective than other currently available oximes in diminishing acute toxicity of OPI $(6,8,18)$.

Our results confirm that the new monopyridinium oximes studied are relatively efficacious against mevinphos toxicity. Their effectiveness differs from each other when they are administered shortly ( $30 \mathrm{sec}$ ) following mevinphos poisoning. Above all, they can be used in relatively high doses in the case of OPI poisonings because of their very low toxicity for mammals. Our data demonstrate that the monopyridinium oxime 2,5-PAEtM appears to be significantly more efficacious than other oximes tested including HI-6.

Our data also suggest that it is necessary to treat mevinphos-poisoned animals as soon as possible because of the rapid onset of life-threatening OPI-induced cholinergic crisis (13). The efficacy of antidotal treatment of mevinphos-induced poisoning significantly decreases if the time interval between poisoning and treatment increases. Thus, not only poisoning with highly toxic OP compounds (3) but also intoxication with some OPI must be treated as soon as possible $(9,18)$.

In conclusion, our data indicate that only monopyridinium oxime 2,5-PAEtM has definite advantages over HI-6 in the treatment of mevinphos poisoning in mice because of its high therapeutic efficacy and low toxicity for mammals.

\section{Acknowledgements}

The authors express their appreciation to Mrs. J. Petrová and Mrs. J. Uhlírová for their technical assistance and help with statistical evaluation.

\section{References}

1. Bardin PGS, van Eeden SF, Moolman JA, Foden AP, Joubert JR. Organophosphate and carbamate poisoning. Arch Intern Med 1994;154:1433-41.

2. Chen H-Ch, Bai D-Y, Jiang Y-P. Effects of HI-6 on muscle acetylcholine receptor: analysis on minimal reaction model. Acta Pharmacol Sin 1996;17:428-31.

3. Dawson RM. Review of oximes available for treatment of nerve agent poisoning. J Appl Toxicol 1994;14:317-31.

4. Fest C, Schmidt KJ. The Chemistry of organophosphorus pesticides. 2nd ed. Springer-Verlag, Berlin 1982; p. 360.

5. Grue CE, Fleming WJ, Busby DG, Hill EF. Assessing hazards of organophosphate pesticides to wildlife. Trans North Am Wildl Nat Resour Conf 1983;48: 200-20.

6. Jokanovic M, Maksimovic M. A comparison of trimedoxime, obidoxime, pralidoxime and HI-6 in the treatment of oral organophosphorus insecticide poisoning in the rat. Arch Toxicol 1995;70:119-23.

7. Kassa J. Comparison of efficacy of two oximes (HI-6 and obidoxime) in soman poisoning in rats. Toxicology 1995; 101:167-74.

8. Kassa J. The possibilities of treatment of poisoning with organophosphorus insecticides in rats. Voj zdrav Listy 1995;64:143-6.

9. Kassa J, Bielavský J. The efficacy of monopyridinium (2-PAAM, 2-PAEM) an bispyridinium (obidoxime, HI-6) oximes against mevinphos in mice. Pharmacol Toxicol 1997;81:144-6

10. Koplovitz I, Stewart JR. A comparison of the efficacy of HI-6 and 2-PAM against soman, tabun, sarin and VX in the rabbit. Toxicol Lett 1994;70:269-79.

11. Kostenis E, Cid HMB, Holzgrabe U, Mohr K. Evidence for a multiple binding mode of bispyridinium-type allosteric modulators of muscarinic receptors. Eur J Pharmacol 1996;314:385-92.

12. Levine R. Recognized and possible effects of pesticides in humans. In: Handbook of Pesticide Toxicology. General Principle. Academic Press: San Diego 1991; 1:275-360.

13. Marrs TC. Organophosphate poisoning. Pharmacol Ther 1993;58:51-66

14. Shih T-M. Comparison of several oximes on reactivation of soman-inhibited blood, brain and tissue cholinesterase activity in rats. Arch Toxicol 1993;67:637-46.

15. Tallarida R, Murray R. Manual of pharmacological calculation with computer programs. Springer-Verlag: New York 1987;p. 145.

16. Tattersall JEH. Ion channel blockade by oximes and recovery of diaphragm muscle from soman poisoning in vitro. Br J Pharmacol 1993;108:1006-15.

17. Teyaratman J. Acute pesticide poisoning: a major global health problem. World Health Stat Q 1990;43:139-44.

18. Vachek J, Kassa J, Fusek J, Bajgar J. New possibilities of treatment of poisoning with organophosphorus compounds. Sbor věd Prací VLA JEP 1993;116:67-95.

19. van Helden HPM, Busker RW, Melchers BPC, Bruijnzeel PLB. Pharmacological effects of oximes: how relevant are they? Arch Toxicol 1996;70:779-86.

Submitted November 1998

Accepted April 1999

Doc. MUDr. Jiři Kassa, CSc., Purkyně Military Medical Academy, 50001 Hradec Králové, Czech Republic. e-mail: kassa@pmfhk.cz 